$$
\begin{aligned}
& \text { DOE/BC/ } 14953-17 \\
& \begin{array}{c}
\text { Quarterly Technical Progress Report } \\
\text { 04/01/96 - 06/30/96 }
\end{array} \\
& 11^{\text {th }} \text { Quarter of the Project }
\end{aligned}
$$

\title{
Increased Oil Production And Reserves From Improved Completion Techniques In The Bluebell Field, Uinta Basin, Utah
}

Contract DE-FC22-92BC14953

\author{
Edith Allison \\ U.S. Department of Energy \\ Bartlesville Project Office \\ Contracting Officer's Representative
}

Craig D. Morgan

Program Manager

Utah Geological Survey

(801) 537-3370

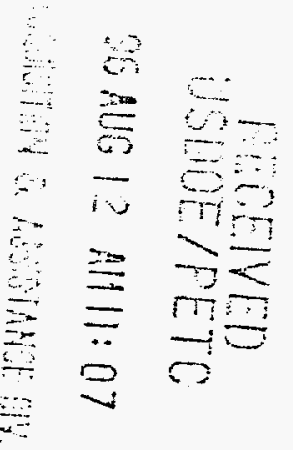

HH 


\section{DISCLAIMER}

Portions of this document may be illegible in electronic image products. Images are produced from the best available original document. 


\section{DISCLAIMER}

This report was prepared as an account of work sponsored by an agency of the United States Government. Neither the United States Government nor any agency thereof, nor any of their employees, makes any warranty, express or implied, or assumes any legal liability or responsibility for the accuracy, completeness, or usefulness of any information, apparatus, product, or process disclosed, or represents that its use would not infringe privately owned rights. Reference herein to any specific commercial product, process, or service by trade name, trademark, manufacturer, or otherwise does not necessarily constitute or imply its endorsement, recommendation, or favoring by the United States Government or any agency thereof. The views and opinions of authors expressed herein do not necessarily state or reflect those of the United States Government or any agency thereof. 
INCREASED OIL PRODUCTION AND RESERVES FROM IMPROVED COMPLETION TECHNIQUES IN THE BLUEBELL FIELD, UINTA BASIN, UTAH

\section{Quarterly Technical Progress Report \\ Quarter 11}

Contract No. DE-FC22-92BC14953

Utah Geological Survey (UGS)

Salt Lake City, Utah

Date of Report: July 30, 1996

Award Date: September 30, 1993

Anticipated Completion: September 30, 1998

Government Award: \$228,653

(current year)

Principal Investigator:

M. Lee Allison (UGS)

Contracting Officer's Representative:

Edith Allison

Bartlesville Project Office

Reporting Period: April 1 - June 30, 1996 


\title{
OBJECTIVE
}

The objective of this project is to increase oil production and reserves in the Uinta Basin by demonstrating improved completion techniques. Low productivity of Uinta Basin wells is caused by gross production intervals of several thousand feet that contain perforated thief zones, water-bearing zones, and unperforated oilbearing intervals. Geologic and engineering characterization and computer simulation of the Green River and Wasatch formations in the Bluebell field will determine reservoir heterogeneities related to fractures and depositional trends. This will be followed by drilling and recompletion of several wells to demonstrate improved completion techniques based on the reservoir characterization. Transfer of the project results will be an ongoing component of the project.

\section{SUMMARY OF TECHNICAL PROGRESS}

\author{
Geostatistical Modeling and Reservoir Simulations
}

\section{Introduction}

The objective of geostatistical modeling and reservoir simulation was to use the available geologic information to create realistic reservoir images of the Bluebell field or portions of the field. Once the reservoir characteristics were established, flow simulations were performed to assess oil production performance. The Bluebell field encompasses several hundred square miles, hence, it was necessary to select a portion of the field for analysis. The geological and engineering characterizations were concentrated in a 20 square-mile ( 51.8 $\mathrm{km}^{2}$ ) area (figure 1) containing 27 wells including the Michelle Ute and Malnar Pike demonstration wells. Most of the wells have been perforated over an interval spanning thousands of feet. About 60 different beds (numbered sequentially from shallow to deep) were correlated over the 20 square-mile $\left(51.8 \mathrm{~km}^{2}\right)$ area. The data for the geostatistical models consists of correlated thicknesses, and calculated porosities and saturations from geophysical well logs.

\section{Approach}

The area shown in figure 1 was divided into a grid consisting of 41 blocks in the $x$-direction and 33 blocks in the $y$-direction. The block dimensions in the both the $x$ and the $y$ directions were 660 feet $(201.3 \mathrm{~m})$ each. Geostatistical methods were then used to generate statistically probable distributions of available reservoir properties in different beds. Porosity and saturation values as functions of spatial locations ( $x$ and $y$ ) were generated. The thicknesses generated using similar computations were then assigned to appropriate grid blocks. Grid block thicknesses along with porosities and saturations completed the reservoir description. Using these properties, it was possible to compute the volume of the original fluids in place (oil, gas, and water) for selected beds. 
Stochastic simulations allow generation of several equally probable realizations. A number of different realizations were created for selected beds. Using a set of these realizations, it was possible to calculate the variability (minimum, maximum, and standard deviation) in the volumes of the initial fluids in place.

The reservoir properties thus generated were input into a black-oil simulator, IMEX, developed by Computer Modeling Group (CMG), Inc. Simulations were performed individually for selected beds. The initial reservoir pressure was assigned based on a 0.5 pounds per square-inch per foot (psi/ft) $(1.05 \mathrm{kPa} / \mathrm{m})$ gradient. In addition to the reservoir properties generated via geostatistical models, the simulator required permeabilities, relative permeabilities, thermodynamic properties, and well constraints. For the purposes of this study, permeabilities were assumed constant at 0.5 milliDarcies (mD). Thermodynamic properties were generated using oil and gas compositions and physical properties determined earlier. A set of oil-water and oil-gas relative permeabilities were assumed. To assess production variability, data from different realizations were input to the flow simulator.

\section{Geostatistics}

Variograms of thickness, porosity, and saturation for each of the beds were generated and a variogram model was constructed. Most of the models are either spherical or exponential and the properties are correlatable up to about 2,000 to 3,000 feet $(610-915 \mathrm{~m})$. The variograms were used for generating property distributions using sequential Gaussian simulations. As an example, the thickness, porosity, and saturation distributions of bed 18 are shown in figures 2,3 and 4 .

The average original oil in place (OOIP) for beds 13 through 44 are tabulated in table 1 . Most of the wells in the 20 square-mile $\left(51.8 \mathrm{~km}^{2}\right.$ ) area produce from below bed 12 . The averages were calculated using 64 realizations for each bed. There is a large gap between the minimum and the maximum values for each of the beds. However, since the data was averaged over a large number of realizations, the standard deviations are reasonable. Thus, the OOIP of a certain bed can be narrowed to the mean value plus or minus the standard deviation with a reasonable degree of confidence. The five most promising beds based on this analysis are:

1. Bed 23 - Average OOIP $=28.8$ million stock-tank-barrels (MMstb)

$$
\text { (4.03 MM-MT) }
$$

2. Bed 18 - Average OOIP $=23.4 \mathrm{MMstb}$ (3.27 MM-MT)

3. Bed 19 - Average OOIP = 22.6 MMstb (3.16 MM-MT)

4. Bed 30 - Average OOIP $=20.3$ MMstb (2.84 MM-MT)

5. Bed 20 - Average OOIP = 17.1 MMstb (2.39 MM-MT)

The total OOIP in the 20 square-mile $\left(51.8 \mathrm{~km}^{2}\right)$ area was about $400 \mathrm{MMstb}$ (56 MM-MT), only a fraction of which has been produced to date. Thus, the field has a tremendous amount of oil still in place. Producing this oil economically is a 
significant technical challenge facing the operators in the field.

\section{Reservoir Simulations}

Reservoir simulations were performed on five of the most promising beds.

The beds were considered isolated and simulated individually. Simulations were performed on 10 different realizations in the time period 1981 through 1995.

Simulated production results for the five beds are summarized in table 2 . In most cases the standard deviation is less than 10 percent of the average production. Based on total production, the beds are ranked as follows:

1. Bed 23 - 993.23 thousand stock-tank-barrels (Mstb) (139.05 M-MT)

2. Bed $19-967.11 \mathrm{Mstb}$ (135.39 M-MT)

3. Bed $18-785.38$ Mstb (109.95 M-MT)

4. Bed $30-431.80 \mathrm{Mstb}(60.45 \mathrm{M}-\mathrm{MT})$

5. Bed 20 - 298.07 Mstb (41.73 M-MT)

This ranking corresponds more or less to the OOIP ranking of the beds except that beds 18 and 19 have reversed order. As a percentage of OOIP most oil is produced from bed 19 (4.3 percent). Thus, with low permeabilities and no fractures, even under ideal conditions, recovery of only about 2 to 4 percent OOIP can be expected from these reservoirs.

In the demonstration wells, the most productive beds are:

Michelle Ute

1. Bed $19-96.25 \mathrm{Mstb}(13.48 \mathrm{M}-\mathrm{MT})$

2. Bed $20-28.43 \mathrm{Mstb}(3.98 \mathrm{M}-\mathrm{MT})$

3. Bed $30-21.73 \mathrm{Mstb}(3.04 \mathrm{M}-\mathrm{MT})$

4. Bed $18-20.48 \mathrm{Mstb}(2.87 \mathrm{M}-\mathrm{MT})$

5. Bed $23-1.71$ Mstb (0.24 M-MT)

Malnar Pike

1. Bed $20-36.67 \mathrm{Mstb}(5.13 \mathrm{M}-\mathrm{MT})$

2. Bed $18-35.53$ Mstb (4.97 M-MT)

3. Bed $19-29.11$ Mstb (4.08 M-MT)

4. Bed $23-18.24 \mathrm{Mstb}(2.55 \mathrm{M}-\mathrm{MT})$

5. Bed $30-15.71 \mathrm{Mstb}(2.19 \mathrm{M}-\mathrm{MT})$

Thus, even though bed 23 contains considerable amount of oil in place, according to the model, it will not be a productive interval in Michelle Ute because of high water saturations. No single bed in the Malnar Pike well contains a large volume of OOIP, even though the total production from all the five beds under ideal conditions should exceed $100 \mathrm{Mstb}$ (14.0 M-MT). 


\section{Summary}

Interpreted log data for thicknesses, porosities, and water saturations were used in a 20-square mile $\left(51.8 \mathrm{~km}^{2}\right)$ portion of the Bluebell field in order to perform geostatistical stochastic simulations. A total of 64 realizations for about 40 beds were generated and analyzed for initial fluids in place. The analyses thus performed provided not only averages of OOIP but also an idea about data uncertainty. The most promising beds in the 20 square-mile $\left(51.8 \mathrm{~km}^{2}\right)$ area were thus determined.

The reservoir characterization information generated using geostatistical modeling for the five most promising beds was input into a black-oil simulator and ten flow simulations were performed for each of the beds. The potential of oil production (with the uncertainty involved) was computed for each of the five beds over the entire 20 square-mile $\left(51.8 \mathrm{~km}^{2}\right)$ area and also for Michelle Ute and Malnar Pike demonstration wells. Even though a number of assumptions were adopted in generating these results, the calculations provide an estimate about the intrinsic merit of the producibility of each of the beds in each of the wells.

These analyses will be refined to include fracturing and other data for the final report on this topic. Production information from some of the wells will also be compared with the model results.

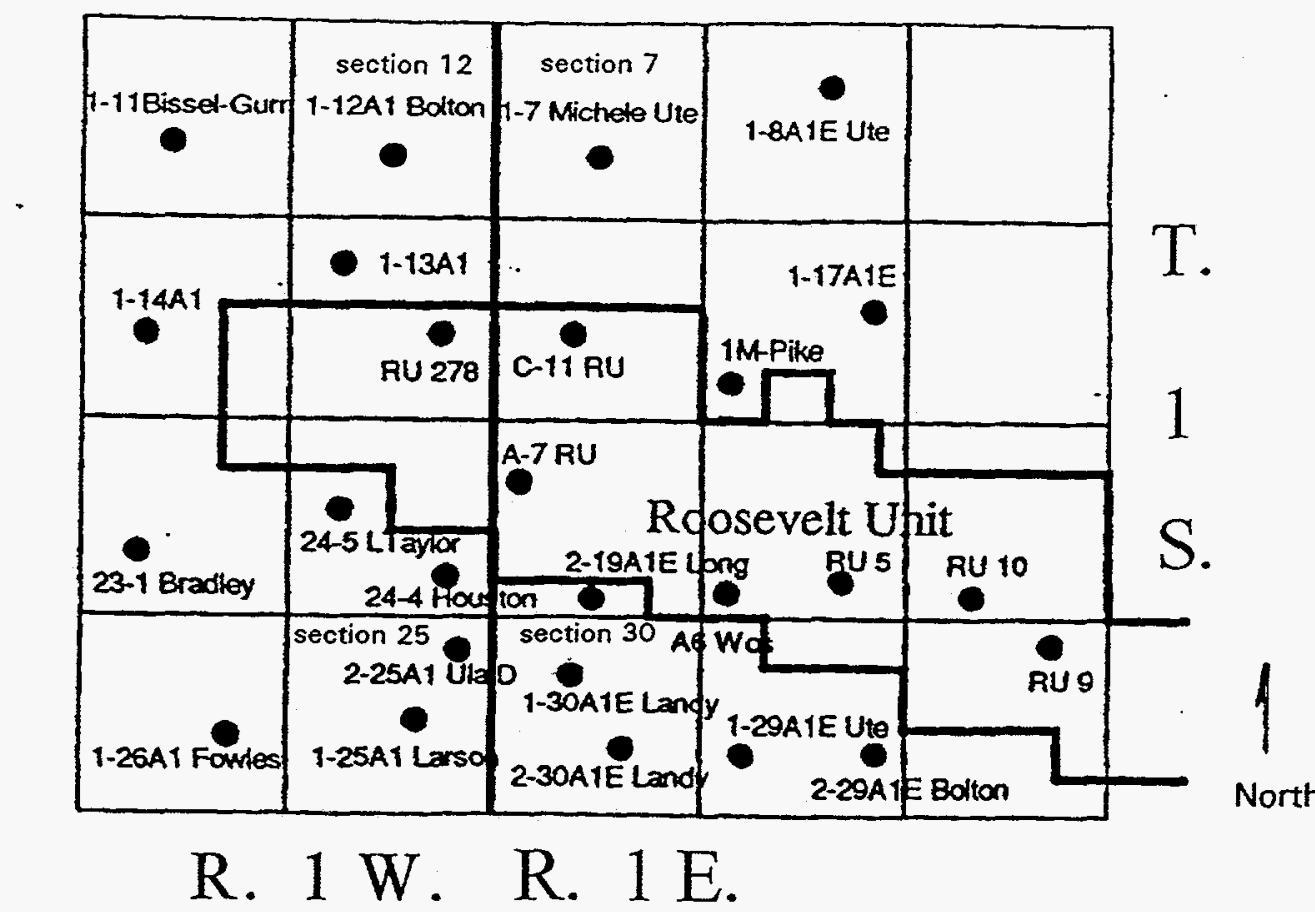

Figure 1. Map of the 20 square-mile area showing well locations and names. 


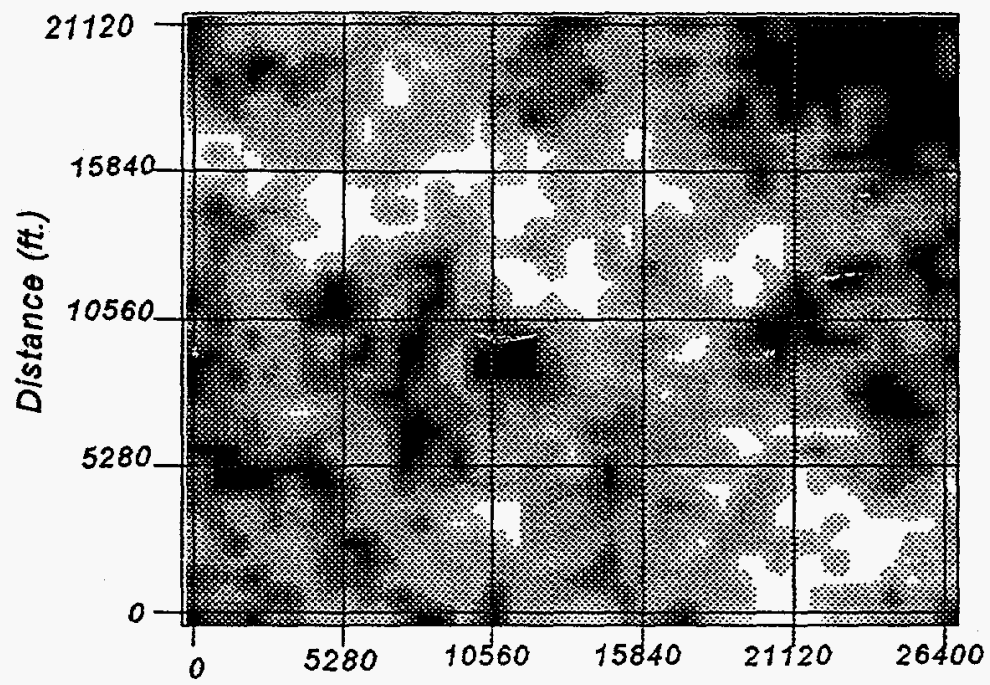

Distance (ft.)

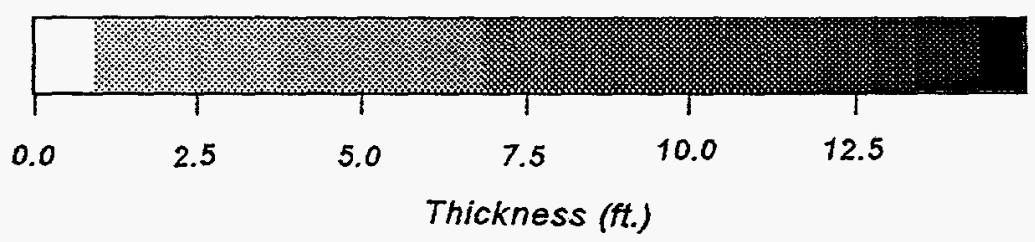

Figure 2. Thickness distribution of bed 18 in the 20 squaremile area. 

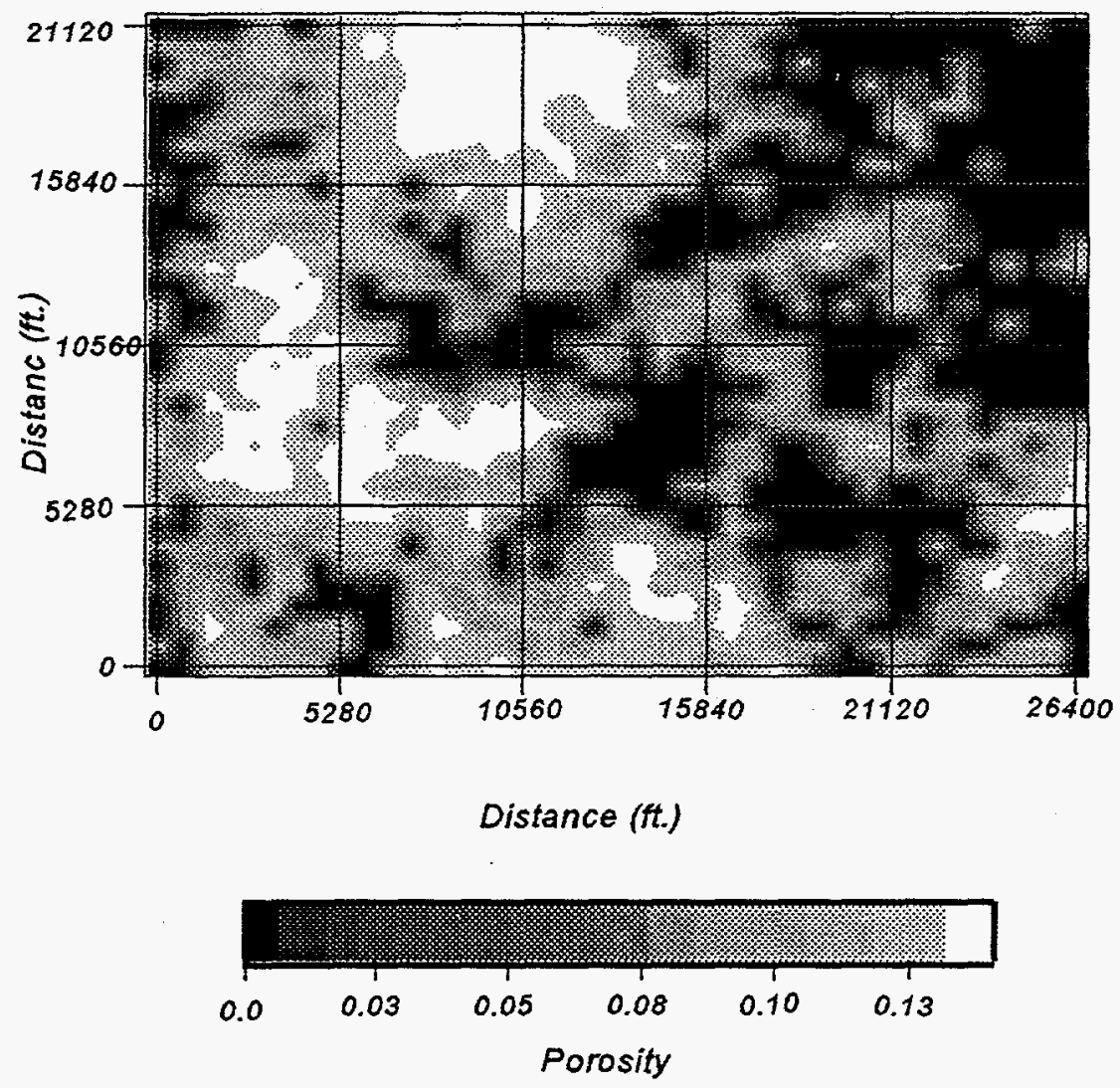

Figure 3. Porosity distribution of bed 18 in the 20 squaremile area. 

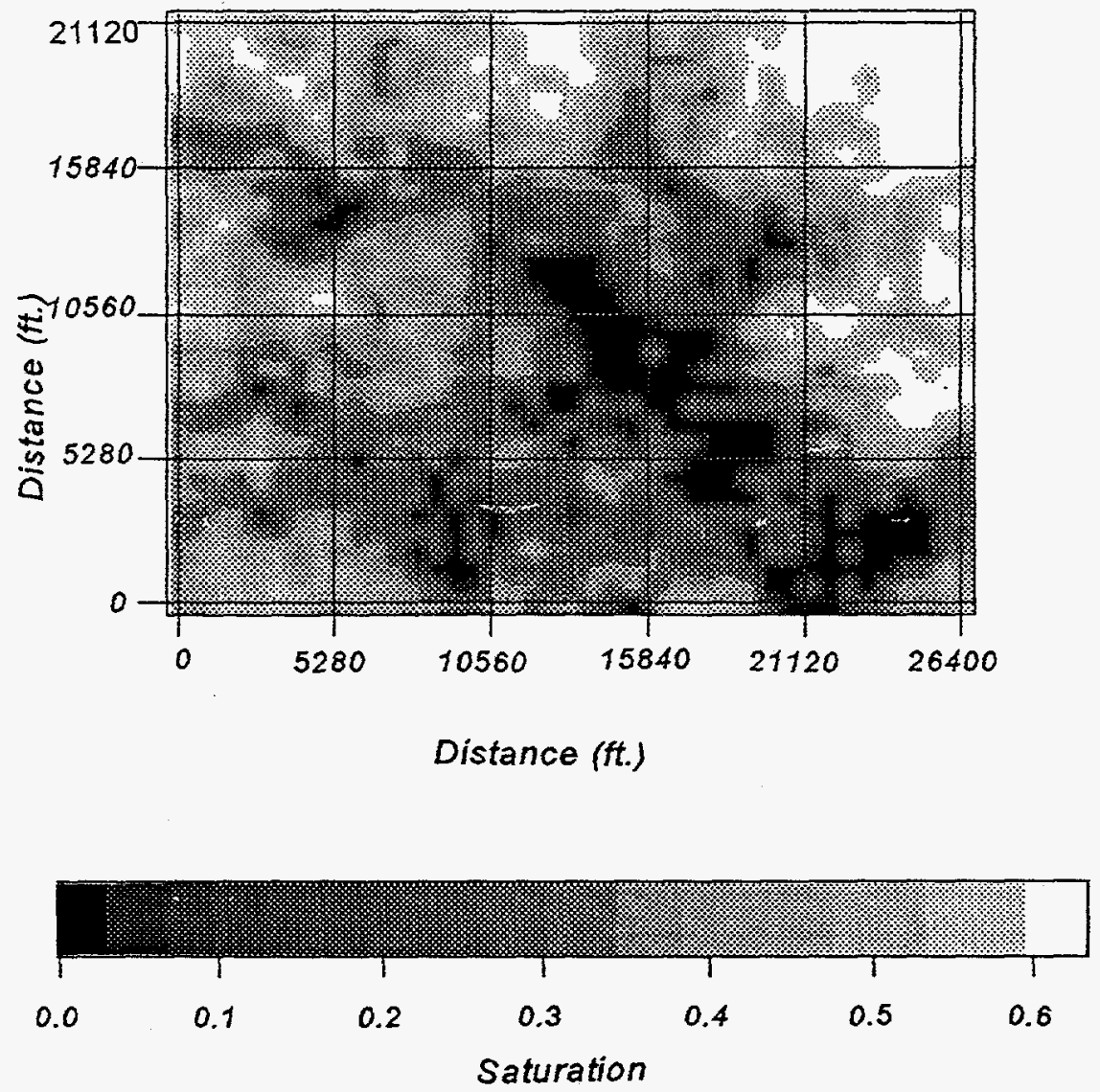

Figure 4. Water saturation distribution of bed 18 in the 20 square-mile area. 
Table 1. Statistics of original-oil-in-place calculations. Sixty-four realizations were used for each bed.

\begin{tabular}{|c|c|c|c|c|}
\hline Bed & $\begin{array}{l}\text { Average } \\
\text { (MMstb) }\end{array}$ & $\begin{array}{l}\text { Minimum } \\
\text { (MMstb) }\end{array}$ & $\begin{array}{l}\text { Maximum } \\
\text { (MMstb) }\end{array}$ & $\begin{array}{c}\text { Standard Deviation } \\
\text { (MMstb) }\end{array}$ \\
\hline 13 & 8.64 & 4.32 & 18.9 & 3.21 \\
\hline $13 a$ & 8.16 & 4.15 & 20.9 & 3.72 \\
\hline $13 b$ & 1.48 & 0.1 & 7.32 & 1.7 \\
\hline 14 & 3.18 & 1.34 & 10.4 & 1.78 \\
\hline 15 & 5.67 & 2.61 & 17.9 & 2.66 \\
\hline 16 & 7.22 & 3.73 & 17.4 & 2.75 \\
\hline $16 \mathrm{a}$ & 10.74 & 5.22 & 23.8 & 4.1 \\
\hline 17 & 8.08 & 5.38 & 17.9 & 2.34 \\
\hline 18 & 23.4 & 17.3 & 42.5 & 4.87 \\
\hline 19 & 22.6 & 18.8 & 33.3 & 3.03 \\
\hline $19 a$ & 16.0 & 9.93 & 24.5 & 3.25 \\
\hline $19 b$ & 6.0 & 3.6 & 11.1 & 1.8 \\
\hline $19 c$ & 6.0 & 3.23 & 14.6 & 2.5 \\
\hline 20 & 17.1 & 12.3 & 32.9 & 3.9 \\
\hline 21 & 3.48 & 1.65 & 10.23 & 1.63 \\
\hline 22 & 4.2 & 2.1 & 11.72 & 1.76 \\
\hline 23 & 28.8 & 22.0 & 46.4 & 4.67 \\
\hline $23 a$ & 3.46 & 1.17 & 12.3 & 2.35 \\
\hline $23 b$ & 5.8 & 2.0 & 21.6 & 3.64 \\
\hline $23 c$ & 9.51 & 4.47 & 19.4 & 3.22 \\
\hline 24 & 2.2 & 0.63 & 9.02 & 1.55 \\
\hline $24 a$ & 1.03 & 0.27 & 4.03 & 0.91 \\
\hline 25 & 1.93 & 0.64 & 5.75 & 1.0 \\
\hline $25 a$ & 2.7 & 0.98 & 9.54 & 1.68 \\
\hline 26 & 5.5 & 3.47 & 11.9 & 1.67 \\
\hline $26 a$ & 3.65 & 2.0 & 7.7 & 1.3 \\
\hline $26 b$ & 4.24 & 1.91 & 12.3 & 2.1 \\
\hline $26 c$ & 4.18 & 1.6 & 12.3 & 2.1 \\
\hline 27 & 14.8 & 10.8 & 24.4 & 2.63 \\
\hline 28 & 8.36 & 4.63 & 18.8 & 2.93 \\
\hline 29 & 5.45 & 1.94 & 12.1 & 2.0 \\
\hline 30 & 20.3 & 14.1 & 37.2 & 4.5 \\
\hline 31 & 15.3 & 9.2 & 31.3 & 4.45 \\
\hline $31 a$ & 6.8 & 3.7 & 13.2 & 2.0 \\
\hline 32 & 10.3 & 6.3 & 24.2 & 3.6 \\
\hline 33 & 6.3 & 3.1 & 19.3 & 3.1 \\
\hline 34 & 8.8 & 4.5 & 22.1 & 3.6 \\
\hline 35 & 1.98 & 0.42 & 7.6 & 1.5 \\
\hline 36 & 8.95 & 5.1 & 22.7 & 3.4 \\
\hline 37 & 7.9 & 4.1 & 18.8 & 3.2 \\
\hline $37 a$ & 1.3 & 0.21 & 6.5 & 1.7 \\
\hline 38 & 7.2 & 3.5 & 16.2 & 2.3 \\
\hline $38 a$ & 1.9 & 0.46 & 5.0 & 1.0 \\
\hline 39 & 9.88 & 5.7 & 21.1 & 3.3 \\
\hline
\end{tabular}




\begin{tabular}{|l|c|c|c|c|}
\hline Bed & $\begin{array}{c}\text { Average } \\
\text { (MMstb) }\end{array}$ & $\begin{array}{c}\text { Minimum } \\
\text { (MMstb) }\end{array}$ & $\begin{array}{c}\text { Maximum } \\
\text { (MMstb) }\end{array}$ & $\begin{array}{c}\text { Standard Deviation } \\
\text { (MMstb) }\end{array}$ \\
\hline 40 & 3.05 & 1.42 & 11.3 & 1.73 \\
\hline 41 & 4.1 & 1.5 & 13.0 & 2.3 \\
\hline $41 \mathrm{a}$ & 5.0 & 1.5 & 15.0 & 2.9 \\
\hline $41 \mathrm{~b}$ & 5.9 & 2.8 & 17.9 & 2.9 \\
\hline $41 \mathrm{c}$ & 6.3 & 2.1 & 20.5 & 4.1 \\
\hline 42 & 0.83 & 0.19 & 3.6 & 0.93 \\
\hline 43 & 1.8 & 0.27 & 9.1 & 2.0 \\
\hline 44 & 5.5 & 1.9 & 18.4 & 3.8 \\
\hline
\end{tabular}


Table 2. Summary of simulated production from the five most significant beds. Ten realizations were simulated for each bed.

BED 18

\begin{tabular}{|c|c|c|c|c|c|c|c|c|c|}
\hline \multirow[t]{2}{*}{ Statistics } & \multicolumn{3}{|c|}{20 Square-Mile Area } & \multicolumn{3}{|c|}{ Michelle Ute } & \multicolumn{3}{|c|}{ Malnar Pike } \\
\hline & $\begin{array}{c}\text { Oil } \\
\text { (Mstb) }\end{array}$ & $\begin{array}{c}\text { Gas } \\
\text { (MMsaf) }\end{array}$ & $\begin{array}{l}\text { Water } \\
\text { (Mstb) }\end{array}$ & $\begin{array}{c}\text { Oil } \\
\text { (Mstb) }\end{array}$ & $\begin{array}{l}\text { Gas } \\
\text { (MMssf) }\end{array}$ & $\begin{array}{l}\text { Water } \\
\text { (Mstb) }\end{array}$ & $\begin{array}{l}\text { Oil } \\
\text { (Mstb) }\end{array}$ & $\begin{array}{l}\text { Gas } \\
\text { (MMscaf) }\end{array}$ & $\begin{array}{l}\text { Water } \\
\text { (Msth) }\end{array}$ \\
\hline average & 785.38 & 742.24 & 42.45 & 20.48 & 16.73 & 11.92 & 35.33 & 36.84 & 0.06 \\
\hline minimum & 681.07 & 680.4 & 41.06 & 18.48 & 11.72 & 10.84 & 13.58 & 19.56 & 0.0 \\
\hline maximum & 897.95 & 809.67 & 43.66 & 22.44 & 19.07 & 18.10 & 49.33 & 44.65 & 0.21 \\
\hline standard & 60.83 & 37.58 & 0.86 & 1.35 & 2.11 & 2.20 & 12.47 & 8.99 & 0.08 \\
\hline
\end{tabular}

BED 19

\begin{tabular}{|c|c|c|c|c|c|c|c|c|c|}
\hline \multirow[t]{2}{*}{ Statistics } & \multicolumn{3}{|c|}{20 Square-Mile Area } & \multicolumn{3}{|c|}{ Michelle Ute } & \multicolumn{3}{|c|}{ Malnar Pike } \\
\hline & $\begin{array}{c}\text { Oil } \\
\text { (Msth) }\end{array}$ & $\begin{array}{c}\text { Gas } \\
\text { (MMscaf) } \\
\end{array}$ & $\begin{array}{r}\text { Water } \\
\text { (Msth) } \\
\end{array}$ & $\begin{array}{c}\text { Oil } \\
\text { (Msth) }\end{array}$ & $\begin{array}{l}\text { Gas } \\
\text { (MMscf) }\end{array}$ & $\begin{array}{l}\text { Water } \\
\text { Mstbl } \\
\end{array}$ & $\begin{array}{l}\text { Oil } \\
\text { (Msth) }\end{array}$ & $\begin{array}{l}\text { Gas } \\
\text { (MMscf) }\end{array}$ & $\begin{array}{l}\text { Water } \\
\text { (Msth) }\end{array}$ \\
\hline average & 967.11 & 898.94 & 39.44 & 96.25 & 80.27 & 7.41 & 29.11 & 26.66 & 0.88 \\
\hline minimum & 894.44 & 874.15 & 38.58 & 82.98 & 70.49 & 7.11 & 17.34 & 16.51 & 0.62 \\
\hline maximum & 1003.0 & 912.6 & 40.65 & 110.01 & 90.88 & 7.67 & 38.23 & 33.29 & 1.02 \\
\hline standard & 31.65 & 13.38 & 0.66 & 8.66 & 6.43 & 0.18 & 7.17 & 5.43 & 0.13 \\
\hline
\end{tabular}

BED 23

\begin{tabular}{|c|c|c|c|c|c|c|c|c|c|}
\hline \multirow[t]{2}{*}{ Statistics } & \multicolumn{3}{|c|}{20 Square-Mile Area } & \multicolumn{3}{|c|}{ Michelle Ute } & \multicolumn{3}{|c|}{ Malnar Pike } \\
\hline & $\begin{array}{c}\text { Oil } \\
\text { (Mstb) }\end{array}$ & $\begin{array}{c}\text { Gas } \\
\text { (MMscf) } \\
\end{array}$ & $\begin{array}{l}\text { Water } \\
\text { (Msth) }\end{array}$ & $\begin{array}{c}\text { Oil } \\
\text { (Msth) }\end{array}$ & $\begin{array}{l}\text { Gas } \\
\text { (MMscf) }\end{array}$ & $\begin{array}{l}\text { Water } \\
\text { (Mstb) }\end{array}$ & $\begin{array}{l}\text { Oil } \\
\text { (Mstb) }\end{array}$ & $\begin{array}{l}\text { Gas } \\
\text { (Msth) }\end{array}$ & $\begin{array}{l}\text { Water } \\
\text { (Msth) }\end{array}$ \\
\hline average & 993.23 & 846.47 & 274.84 & 1.71 & 1.51 & 73.01 & 18.24 & 15.31 & 8.27 \\
\hline minimum & 877.36 & 754.64 & 221.01 & $\ldots 0.0$ & 0.0 & 0.0 & 11.81 & 9.91 & 4.87 \\
\hline maximum & 1106.7 & 944.67 & 349.62 & 8.55 & 7.49 & 129.63 & 31.99 & 26.50 & 11.86 \\
\hline standard & 77.28 & 65.16 & 35.28 & 3.44 & 3.05 & $4 \dot{6} .87$ & 6.85 & 5.61 & 2.32 \\
\hline
\end{tabular}


BED 30

\begin{tabular}{|c|c|c|c|c|c|c|c|c|c|}
\hline \multirow[t]{2}{*}{ Statistics } & \multicolumn{3}{|c|}{20 Square-Mile Area } & \multicolumn{3}{|c|}{ Michelle Ute } & \multicolumn{3}{|c|}{ Malnar Pike } \\
\hline & $\begin{array}{c}\text { Oil } \\
\text { (Msth) }\end{array}$ & $\begin{array}{c}\text { Gas } \\
(\mathrm{MM} M s c f) \\
\end{array}$ & $\begin{array}{l}\text { Water } \\
\text { (Msth) }\end{array}$ & $\begin{array}{c}\text { Oil } \\
\text { (Mstb) }\end{array}$ & $\begin{array}{l}\text { Gas } \\
\text { (MMscf) }\end{array}$ & $\begin{array}{l}\text { Water } \\
\text { (Msth) } \\
\end{array}$ & $\begin{array}{l}\text { Oil } \\
\text { (Msth) }\end{array}$ & $\begin{array}{l}\text { Gas } \\
\text { (Msth) }\end{array}$ & $\begin{array}{l}\text { Water } \\
\text { (Msth) }\end{array}$ \\
\hline average & 431.80 & 370.78 & 268.57 & 21.73 & 18.45 & 29.96 & 15.71 & 13.25 & 22.97 \\
\hline minimum & 351.28 & 301.11 & 217.24 & 12.41 & 10.55 & 23.58 & 7.58 & 6.37 & 19.99 \\
\hline maximum & 496.39 & 422.1 & 374.22 & 28.29 & 24.05 & 42.06 & 27.79 & 23.59 & 26.45 \\
\hline $\begin{array}{l}\text { standard } \\
\text { deviation }\end{array}$ & 46.85 & 39.99 & 47.77 & 6.13 & 5.20 & 6.12 & 6.66 & 5.68 & 2.14 \\
\hline
\end{tabular}

BED 20

\begin{tabular}{|c|c|c|c|c|c|c|c|c|c|}
\hline \multirow[t]{2}{*}{ Statistics } & \multicolumn{3}{|c|}{20 Square-Mile Area } & \multicolumn{3}{|c|}{ Michelle Ute } & \multicolumn{3}{|c|}{ Malnar Pike } \\
\hline & $\begin{array}{c}\text { Oil } \\
\text { (Msthl }\end{array}$ & $\begin{array}{c}\text { Gas } \\
-\quad(\mathrm{MMscf}) \\
\end{array}$ & $\begin{array}{l}\text { Water } \\
\text { (Mstb) }\end{array}$ & $\begin{array}{c}\text { Oil } \\
\text { (Msth) }\end{array}$ & $\begin{array}{l}\text { Gas } \\
\text { (MMsaf) }\end{array}$ & $\begin{array}{l}\text { Water } \\
\text { (Mstbl }\end{array}$ & $\begin{array}{l}\text { Oil } \\
(\mathrm{Msth})\end{array}$ & $\begin{array}{l}\text { Gas } \\
\text { (Msth) }\end{array}$ & $\begin{array}{l}\text { Water } \\
\text { (Msth) }\end{array}$ \\
\hline average & 298.07 & 256.42 & 263.89 & 28.43 & 24.16 & 22.08 & 36.67 & 29.40 & 20.77 \\
\hline minimum & 243.00 & 212.91 & 223.4 & 17.89 & 15.21 & 15.58 & 23.96 & 19.07 & 16.24 \\
\hline maximum & 370.97 & 314.43 & 330.56 & 43.91 & 37.32 & 31.70 & 62.51 & 51.64 & 27.66 \\
\hline $\begin{array}{l}\text { standard } \\
\text { deviation }\end{array}$ & 48.39 & 38.03 & 30.72 & 8.65 & 7.35 & 5.51 & 12.96 & 11.21 & 4.69 \\
\hline
\end{tabular}

